\section{Growth, Survival, and Aesthetic Quality of Boxwood Cultivars as Affected by Landscape Exposure}

\author{
Alice Le Duc ${ }^{1}$, Linda R. Parsons ${ }^{2}$, and John C. Pair ${ }^{3}$ \\ Department of Horticulture, Forestry and Recreation Resources, 2021 \\ Throckmorton Plant Science Center, Kansas State University, Manhattan, \\ KS 66506-5506
}

Additional index words. Buxus sp., leaf temperature, soil temperature

\begin{abstract}
Three cultivars of boxwood, 'Winter Gem' (Buxus microphylla Sieb. \& Zucc.), 'Green Velvet', and 'Green Mountain' [B. sinica (Rehd. \& Wils.) Cheng var. insularis (Nakai) M. Cheng X B. sempervirens L. 'Suffruticosa' L.], were planted in 12 different landscape exposures (N, ENE, NNE, E, SSE, ESE, S, WSW, SSW, W, NNW, WNW) at Manhattan and Wichita, Kans., representing U.S. Dept. of Agriculture hardiness zones 5 and 6, respectively. In Kansas, winter stress is often the greatest threat to plant survival, and Winter 1995-96 was one of great extremes. Official lows of $-25^{\circ} \mathrm{C}$ for Manhattan and $-23{ }^{\circ} \mathrm{C}$ for Wichita were recorded, along with sharp 24-hour temperature drops of 31-32 ${ }^{\circ} \mathrm{C}$ in January and March. Differences in cultivar performance were noted between sites. Better winter quality was exhibited by 'Green Velvet' and 'Green Mountain', although significant bronzing occurred on the former in Manhattan. Locations on N, ENE, NNE, NNW, and WNW exposures resulted in better plant quality of all cultivars, whereas plant performance was poorer at $S$ and $S E$ exposures. Differences in canopy temperatures of up to $15.7^{\circ} \mathrm{C}$ were recorded, on the same cold winter day, between NNW and ESE. Recovery from winter dieback and growth during Summer 1996 varied with cultivar, site, and exposure. 'Winter Gem' grew most in height, and 'Green Velvet' grew most overall at Manhattan. Growth rates were dependent on exposure, with greater growth at NNE, E, SSW, and WNW. Performance of 'Green Velvet' and 'Green Mountain' indicated that they could be used in any exposure with conditions similar to those of the test sites.
\end{abstract}

Great importance is placed on evergreen plants in the landscape industry because they serve as primary design components in many landscapes. In regions of the country where cold winters limit the number of species that remain evergreen, mainly conifers are used, because very few broadleaf-evergreen plants are available. Kansas winters are not only cold but usually involve numerous freezing and thawing sequences that, when coupled with the desiccating effects of wind and sun, place considerable stress on ornamental plants (Pair, 1987; Pair and Still, 1982). Several cultivars of Buxus, broadleaf evergreen boxwood, have been reported to be hardy in USDA hardiness zones 4 and 5 (Hawke, 1994; Martinez, 1995). Three cultivars were selected to evaluate the effects of microclimate on landscape-exposure and on growth, survival, and aesthetic qualities at two different sites in Kansas.

Received for publication 25 Feb. 1999. Accepted for publication 20 June 1999. Contribution \#99-237-J from the Kansas Agr. Expt. Sta. We wish to acknowledge the donation of Buxus microphylla 'Winter Gem' by Greenleaf Nurseries, Park Hill, Okla., and Buxus 'Green Mountain' and 'Green Velvet' by Nortex Tawakoni Plant Farm, Wills Point, Tex. The cost of publishing this paper was defrayed in part by the payment of page charges. Under postal regulations, this paper therefore must be hereby marked advertisement solely to indicate this fact. ${ }^{1}$ Adjunct Professor, California Polytechnic State Univ., San Luis Obispo, Calif.

${ }^{2}$ Research Assistant. John C. Pair Horticulture Ctr., Wichita, Kans.

${ }^{3}$ Professor (deceased). John C. Pair Horticulture Ctr., Wichita, Kans. residential dwellings. The structures were cross-shaped with four equal arms and aligned due north/south/east/west to create 12 different geographic direction exposures (N, ENE, NNE, E, SSE, ESE, S, WSW, SSW, W, NNW, and WNW) (Fig. 1). The cross design also created both inside and outside corners. Each structure was $2.44 \mathrm{~m}$ tall, $1.52 \mathrm{~m}$ long on each side, and $2.74 \mathrm{~m}$ high at the gabled peaks at the end of each arm, and had a $64 \mathrm{~cm}$ roof overhang. The structures were painted with green all-weather paint. All structures were located on level ground spaced such that no building or landscape plants shaded any of the structures, thus only structure-exposure related shade patterns affected the study. The use of three structures at each site allowed three replicates of each cultivar to be planted at different locations within each of the 12 different exposures. This effectively resulted in a randomized complete-block/split-plot design at each site with exposure as the main plot and cultivar as the split plot. Overall, the experiment was a split-split plot design, with site as the main plot, exposure as the split plot, and cultivar as the split-split plot. Experimental units were individual shrubs.

The three cultivars selected for study were 'Green Velvet' and 'Green Mountain' [Buxus sinica (Rehd. \& Wils.) Cheng var. insularis (Nakai) M. Cheng $\times$ B . sempervirens $L$. 'Suffruticosa' L. (purportedly Batdorf, 1995)] and 'Winter Gem' (B. microphylla Sieb. \& Zucc.). Sheridan Nurseries, the hybridizers of 'Green Mountain' and 'Green Velvet', describe 'Green Mountain' as an oval-shaped, upright selection and 'Green Velvet' as a round, full-bodied cultivar. Twelve plants of each cultivar were planted around the structures in June 1995. Adequate soil moisture was maintained throughout the three growing seasons. Plants were treated as needed to remain free of insects and disease. Winter plant quality and injury to the plants were rated visually in tures at each site were used to simulate typical

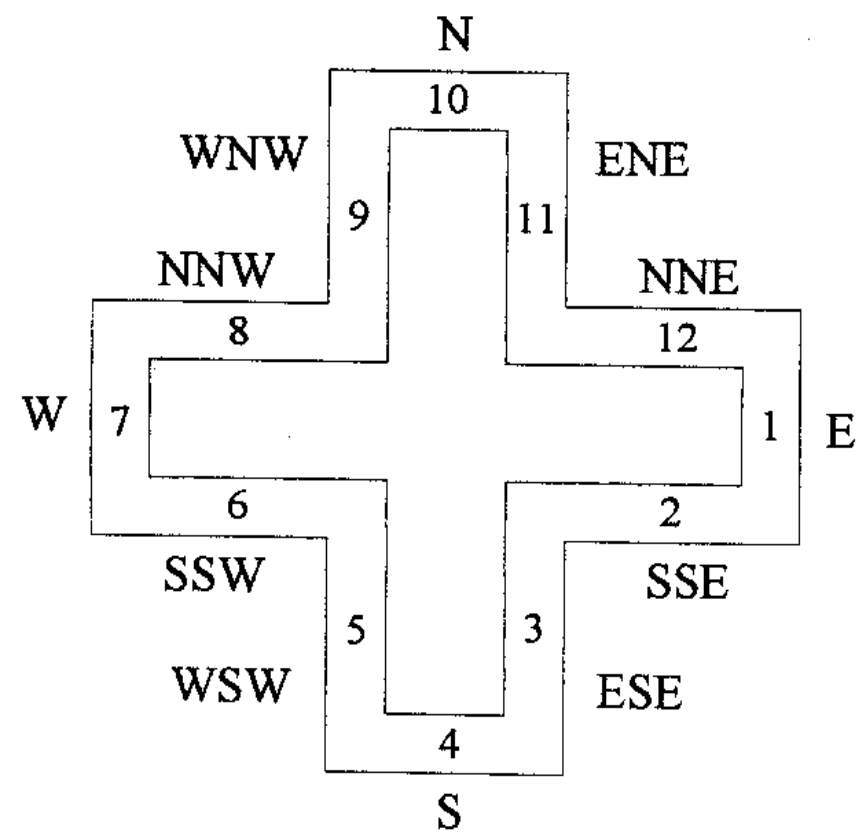

Fig. 1. Diagram of exposure hut showing 12 exposures and thermocouple positions. 
Table 1. Leaf and soil temperatures recorded for all exposures on the coldest winter days in 1996 at Wichita and Manhattan, Kans.

\begin{tabular}{|c|c|c|c|c|c|c|c|c|c|c|c|c|}
\hline \multirow[b]{3}{*}{ Exposure } & \multicolumn{6}{|c|}{ Leaf temp $\left({ }^{\circ} \mathrm{C}\right)$} & \multicolumn{6}{|c|}{ Soil temp $\left({ }^{\circ} \mathrm{C}\right)$} \\
\hline & \multicolumn{3}{|c|}{ Wichita, 18 Jan. } & \multicolumn{3}{|c|}{ Manhattan, 2 Feb. } & \multicolumn{3}{|c|}{$\begin{array}{c}\text { Wichita, } 18 \text { Jan. } \\
\end{array}$} & \multicolumn{3}{|c|}{ Manhattan, 2 Feb. } \\
\hline & $1100 \mathrm{HR}$ & $1300 \mathrm{HR}$ & $1500 \mathrm{HR}$ & $1100 \mathrm{HR}$ & $1300 \mathrm{HR}$ & $1500 \mathrm{HR}$ & $1100 \mathrm{HR}$ & $1300 \mathrm{HR}$ & $1500 \mathrm{HR}$ & $1100 \mathrm{HR}$ & $1300 \mathrm{HR}$ & $1500 \mathrm{HR}$ \\
\hline $\mathrm{N}$ & -14.0 & -12.0 & -11.0 & $--^{2}$ & --- & --- & -5.0 & -4.5 & -4.5 & -6.8 & -6.9 & -7.0 \\
\hline NNE & -13.5 & -12.5 & -11.0 & -15.7 & -18.2 & -16.9 & -0.5 & -0.5 & -0.5 & -4.2 & -4.1 & -4.2 \\
\hline E & -13.5 & -12.0 & -11.0 & -19.7 & -16.2 & -16.2 & -1.5 & -1.5 & -1.5 & -2.3 & -2.4 & -2.4 \\
\hline SSE & -13.5 & -11.0 & -10.5 & -13.9 & -7.3 & -14.3 & -0.5 & -0.5 & -0.5 & -4.3 & -4.2 & -3.9 \\
\hline ESE & -13.0 & -11.0 & -11.0 & -7.7 & -2.7 & -13.1 & 0.5 & 0.5 & 0.5 & -3.7 & -3.4 & -3.0 \\
\hline SSW & -13.5 & -10.5 & -9.0 & -17.3 & -12.6 & -11.0 & 1.0 & 1.5 & 1.5 & -4.2 & -4.1 & -3.9 \\
\hline W & -14.0 & -12.0 & -10.5 & -15.4 & -13.4 & -13.5 & -2.0 & -2.0 & -2.0 & -5.6 & -4.8 & -4.4 \\
\hline NNW & -14.0 & -11.5 & -11.0 & -21.0 & -18.4 & -15.5 & -1.0 & -1.0 & -1.0 & -7.8 & -7.3 & -7.9 \\
\hline WNW & -14.0 & -12.0 & -11.0 & --- & --- & --- & -1.0 & -1.0 & -1.0 & --- & --- & --- \\
\hline \multicolumn{13}{|l|}{ Difference } \\
\hline between extremes & 1.0 & 1.5 & 2.0 & 13.3 & 15.7 & 7.8 & 7.0 & 6.5 & 6.5 & 5.7 & 5.4 & 6.0 \\
\hline
\end{tabular}

${ }^{2}$ Data incomplete because of rodent injury to the probe wires.

Table 2. Effect of landscape exposures on appearance quality ${ }^{z}$ of three boxwood cultivars, based on visual rating, at two locations in Kansas. ${ }^{y}$

\begin{tabular}{|c|c|c|c|c|c|c|c|c|c|c|c|c|}
\hline \multirow[b]{3}{*}{ Exposure } & \multicolumn{6}{|c|}{ Winter quality $^{x}$} & \multicolumn{6}{|c|}{ Summer qualityw $^{w}$} \\
\hline & \multicolumn{2}{|c|}{ Green Mountain } & \multicolumn{2}{|c|}{ Green Velvet } & \multicolumn{2}{|c|}{ Winter Gem } & \multicolumn{2}{|c|}{ Green Mountain } & \multicolumn{2}{|c|}{ Green Velvet } & \multicolumn{2}{|c|}{ Winter Gem } \\
\hline & Manhattan & $\overline{\text { Wichita }}$ & Manhattan & $\overline{\text { Wichita }}$ & Manhattan & Wichita & Manhattan & Wichita & Manhattan & $\overline{\text { Wichita }}$ & Manhattan & Wichita \\
\hline $\mathrm{N}$ & $7.22 \mathrm{a}^{\mathrm{v}}$ & $7.44 \mathrm{a}$ & $7.28 \mathrm{a}$ & $7.44 \mathrm{a}$ & $6.50 \mathrm{a}$ & $7.44 \mathrm{a}$ & $8.17 \mathrm{a}$ & $8.72 \mathrm{a}$ & $8.78 \mathrm{a}$ & $8.44 \mathrm{a}$ & $8.78 \mathrm{a}$ & $8.11 \mathrm{a}$ \\
\hline NNE & $6.67 \mathrm{a}$ & $8.00 \mathrm{a}$ & $7.39 \mathrm{a}$ & $8.22 \mathrm{a}$ & $6.83 \mathrm{a}$ & $7.89 \mathrm{a}$ & $7.78 \mathrm{a}$ & $8.67 \mathrm{a}$ & $8.67 \mathrm{a}$ & $8.61 \mathrm{a}$ & $8.56 \mathrm{a}$ & $8.28 \mathrm{a}$ \\
\hline $\mathrm{E}$ & $6.00 \mathrm{a}$ & $6.83 \mathrm{a}$ & $6.94 \mathrm{a}$ & $6.83 \mathrm{a}$ & $5.94 \mathrm{a}$ & $7.22 \mathrm{a}$ & $7.61 \mathrm{a}$ & $8.03 \mathrm{a}$ & $8.67 \mathrm{a}$ & $8.39 \mathrm{a}$ & $8.67 \mathrm{a}$ & $8.56 \mathrm{a}$ \\
\hline SSE & $6.39 \mathrm{a}$ & $6.22 \mathrm{a}$ & $6.72 \mathrm{a}$ & $6.50 \mathrm{a}$ & $5.22 \mathrm{a}$ & $6.72 \mathrm{~b}$ & $7.06 \mathrm{a}$ & $7.92 \mathrm{a}$ & $8.67 \mathrm{a}$ & $8.00 \mathrm{a}$ & $7.11 \mathrm{a}$ & $8.50 \mathrm{a}$ \\
\hline ESE & $6.00 \mathrm{a}$ & $6.56 \mathrm{a}$ & $6.06 \mathrm{a}$ & $7.11 \mathrm{a}$ & $5.44 \mathrm{a}$ & $5.78 \mathrm{a}$ & $6.89 \mathrm{a}$ & $8.00 \mathrm{a}$ & $8.39 \mathrm{a}$ & $8.67 \mathrm{a}$ & $7.72 \mathrm{a}$ & $6.67 \mathrm{a}$ \\
\hline SSW & $4.94 \mathrm{a}$ & $6.28 \mathrm{a}$ & $5.50 \mathrm{a}$ & $6.22 \mathrm{a}$ & $4.11 \mathrm{a}$ & $7.06 \mathrm{~b}$ & $5.83 \mathrm{a}$ & $8.17 \mathrm{~b}$ & $8.00 \mathrm{a}$ & $8.31 \mathrm{a}$ & $6.28 \mathrm{a}$ & $8.22 \mathrm{~b}$ \\
\hline W & $6.72 \mathrm{a}$ & $6.50 \mathrm{a}$ & $6.44 \mathrm{a}$ & $6.61 \mathrm{a}$ & $5.83 \mathrm{a}$ & $7.17 \mathrm{a}$ & $7.50 \mathrm{a}$ & $8.22 \mathrm{a}$ & $8.48 \mathrm{a}$ & $8.64 \mathrm{a}$ & $8.56 \mathrm{a}$ & $8.44 \mathrm{a}$ \\
\hline NNW & $7.33 \mathrm{a}$ & $7.22 \mathrm{a}$ & $7.56 \mathrm{a}$ & $7.67 \mathrm{a}$ & $6.44 \mathrm{a}$ & $7.39 \mathrm{a}$ & $8.11 \mathrm{a}$ & $8.56 \mathrm{a}$ & $8.61 \mathrm{a}$ & $8.56 \mathrm{a}$ & $8.40 \mathrm{a}$ & $8.39 \mathrm{a}$ \\
\hline WNW & $7.28 \mathrm{a}$ & $7.44 \mathrm{a}$ & $7.44 \mathrm{a}$ & $7.33 \mathrm{a}$ & $6.44 \mathrm{a}$ & $7.44 \mathrm{a}$ & $8.11 \mathrm{a}$ & $8.56 \mathrm{a}$ & $8.61 \mathrm{a}$ & $8.44 \mathrm{a}$ & $8.61 \mathrm{a}$ & $8.56 \mathrm{a}$ \\
\hline
\end{tabular}

${ }^{2}$ Expressed as least square mean.

${ }^{y}$ Symbols: $\mathrm{N}=$ north, ENE = east northeast, $\mathrm{NNE}=$ north northeast, $\mathrm{E}=$ east, $\mathrm{SSE}=$ south southeast, $\mathrm{ESE}=$ east southeast, $\mathrm{S}=$ south, WSW = west southwest, $\mathrm{SSW}$ = south southwest, $\mathrm{W}=$ west, $\mathrm{NNW}=$ north northwest, $\mathrm{WNW}=$ west northwest.

${ }^{\times}$Scale of 0-9: $9=$ green, no bronzing; $5=50 \%$ of foliage bronzed, reddish-brown; $0=$ all foliage bronzed, brown/gray-brown.

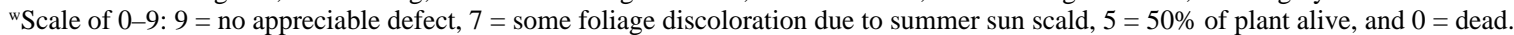

${ }^{\vee}$ Mean separation between sites for each cultivar, and exposure $(P \leq 0.05)$.

Table 3. Effect of landscape exposures in the severe Winter 1995-96 and for the length of the experiment, June 1995 to Mar. 1998, on boxwood growth (mean change in height ${ }^{2}$ ) of three boxwood cultivars at two locations in Kansas. ${ }^{y}$

\begin{tabular}{|c|c|c|c|c|c|c|c|c|c|c|c|c|}
\hline \multirow[b]{2}{*}{ Site } & \multicolumn{12}{|c|}{ Exposure } \\
\hline & $\mathrm{N}$ & ENE & $\mathrm{NNE}$ & E & SSE & ESE & $\mathrm{S}$ & WSW & SSW & $\mathrm{W}$ & NNW & WNW \\
\hline \multicolumn{13}{|c|}{ May 1995-Sept. 1996} \\
\hline \multicolumn{13}{|c|}{ Green Mountain } \\
\hline Wichita & $-0.67 \mathrm{a}$ & $0.33 \mathrm{a}$ & $-1.83 \mathrm{a}$ & $-0.17 \mathrm{a}$ & $-0.50 \mathrm{a}$ & $-0.17 \mathrm{a}$ & $0.33 \mathrm{a}$ & $-1.83 \mathrm{a}$ & $-0.83 \mathrm{a}$ & $0.00 \mathrm{a}$ & $0.17 \mathrm{a}$ & $0.50 \mathrm{a}$ \\
\hline \multicolumn{13}{|l|}{ Green Velvet } \\
\hline Manhattan & $1.50 \mathrm{a}$ & $-1.83 \mathrm{a}$ & $2.00 \mathrm{a}$ & $1.67 \mathrm{a}$ & $0.50 \mathrm{a}$ & $1.33 \mathrm{a}$ & $-0.17 \mathrm{a}$ & $0.17 \mathrm{a}$ & $1.83 \mathrm{a}$ & $0.17 \mathrm{a}$ & $0.17 \mathrm{a}$ & $2.50 \mathrm{a}$ \\
\hline Wichita & $9.17 \mathrm{a}$ & $9.00 \mathrm{~b}$ & $11.17 \mathrm{~b}$ & $10.17 \mathrm{~b}$ & $9.00 \mathrm{a}$ & $12.28 \mathrm{~b}$ & $8.50 \mathrm{a}$ & $10.67 \mathrm{~b}$ & $7.33 \mathrm{a}$ & $8.83 \mathrm{a}$ & $8.17 \mathrm{a}$ & $10.17 \mathrm{a}$ \\
\hline \multicolumn{13}{|c|}{ June 1995-Mar. 1998} \\
\hline \multicolumn{13}{|c|}{ Green Mountain } \\
\hline Manhattan & $-0.17 \mathrm{a}^{\mathrm{x}}$ & $1.00 \mathrm{a}$ & $2.83 \mathrm{a}$ & $0.83 \mathrm{a}$ & $0.50 \mathrm{a}$ & $-0.83 \mathrm{a}$ & $2.33 \mathrm{a}$ & $-0.33 \mathrm{a}$ & $1.11 \mathrm{a}$ & $-1.50 \mathrm{a}$ & $4.83 \mathrm{a}$ & $3.33 \mathrm{a}$ \\
\hline Wichita & $0.50 \mathrm{a}$ & $2.67 \mathrm{a}$ & $0.83 \mathrm{a}$ & $1.83 \mathrm{a}$ & $0.50 \mathrm{a}$ & $-0.17 \mathrm{a}$ & $0.33 \mathrm{a}$ & $-1.00 \mathrm{a}$ & $0.33 \mathrm{a}$ & $1.33 \mathrm{a}$ & $1.00 \mathrm{a}$ & $2.00 \mathrm{a}$ \\
\hline \multicolumn{13}{|l|}{ Green Velvet } \\
\hline
\end{tabular}

${ }^{2}$ Expressed as least square mean.

${ }^{y}$ Symbols: $\mathrm{N}=$ north, $\mathrm{ENE}=$ east northeast, $\mathrm{NNE}=$ north northeast, $\mathrm{E}=$ east, $\mathrm{SSE}=$ south southeast, $\mathrm{ESE}=$ east southeast, $\mathrm{S}=$ south, WSW = west southwest, $\mathrm{SSW}$ = south southwest, $\mathrm{W}=$ west, $\mathrm{NNW}=$ north northwest, $\mathrm{WNW}=$ west northwest.

${ }^{\mathrm{x}}$ Mean separation between sites for each cultivar and exposure $(P \leq 0.05)$. 
Table 4. Leaf and soil temperatures recorded for all exposures on a representative hot summer day in 1996 at Wichita and Manhattan, Kans.

\begin{tabular}{|c|c|c|c|c|c|c|c|c|c|c|c|c|}
\hline \multirow[b]{3}{*}{ Exposure } & \multicolumn{6}{|c|}{ Leaf temp $\left({ }^{\circ} \mathrm{C}\right)$} & \multicolumn{6}{|c|}{ Soil temp $\left({ }^{\circ} \mathrm{C}\right)$} \\
\hline & \multicolumn{3}{|c|}{ Wichita, 20 July } & \multicolumn{3}{|c|}{ Manhattan, 19 July } & \multicolumn{3}{|c|}{ Wichita, 20 July } & \multicolumn{3}{|c|}{ Manhattan, 19 July } \\
\hline & $1100 \mathrm{HR}$ & $1300 \mathrm{HR}$ & $1500 \mathrm{HR}$ & $1100 \mathrm{HR}$ & $1300 \mathrm{HR}$ & $1500 \mathrm{HR}$ & $1100 \mathrm{HR}$ & $1300 \mathrm{HR}$ & $1500 \mathrm{HR}$ & $1100 \mathrm{HR}$ & $1300 \mathrm{HR}$ & $1500 \mathrm{HR}$ \\
\hline $\mathrm{N}$ & 36.5 & 28.5 & 30.0 & $---^{z}$ & --- & --- & 27.5 & 28.5 & 28.0 & 25.3 & 25.6 & 25.3 \\
\hline ENE & 36.5 & 39.0 & 33.5 & 35.2 & 30.7 & 33.6 & 26.5 & 27.5 & 27.5 & 23.9 & 24.1 & 24.2 \\
\hline NNE & 37.0 & 34.5 & 35.0 & 48.4 & 27.2 & 30.0 & 27.0 & 28.0 & 27.5 & 24.0 & 24.3 & 24.3 \\
\hline $\mathrm{E}$ & 35.0 & 40.0 & 36.0 & 42.0 & 38.4 & 36.5 & 26.0 & 27.0 & 27.0 & 24.7 & 24.9 & 25.1 \\
\hline SSE & 34.0 & 38.5 & 39.0 & 48.6 & 43.4 & 35.9 & 26.0 & 27.0 & 29.0 & 24.8 & 25.2 & 25.5 \\
\hline ESE & 32.5 & 38.5 & 36.0 & 47.7 & 37.3 & 36.3 & 26.0 & 26.5 & 27.0 & 24.5 & 24.8 & 24.9 \\
\hline $\mathrm{S}$ & 30.0 & 39.0 & 39.0 & 38.2 & 40.7 & 44.6 & 27.5 & 28.0 & 28.5 & 25.0 & 25.2 & 25.5 \\
\hline WSW & 27.0 & 34.0 & 42.0 & 34.1 & 38.4 & 42.7 & 25.5 & 26.5 & 27.5 & 24.3 & 24.5 & 24.8 \\
\hline SSW & 30.0 & 36.0 & 39.0 & 33.9 & 37.8 & 39.4 & 25.5 & 26.0 & 27.5 & 24.8 & 24.8 & 25.0 \\
\hline W & 28.5 & 34.0 & 41.0 & 33.9 & 26.3 & 38.2 & 25.5 & 26.5 & 28.0 & 25.0 & 25.2 & 25.4 \\
\hline NNW & 30.0 & 32.0 & 35.0 & 33.5 & 25.6 & 37.6 & 25.5 & 26.0 & 26.5 & 24.7 & 24.9 & 25.0 \\
\hline WNW & 29.5 & 32.0 & 38.5 & --- & --- & --- & 26.0 & 27.0 & 27.5 & --- & --- & --- \\
\hline Difference & & & & & & & & & & & & \\
\hline between extremes & 10.0 & 11.5 & 12.0 & 15.1 & 17.8 & 14.6 & 2.0 & 2.5 & 2.5 & 1.4 & 1.5 & 1.3 \\
\hline
\end{tabular}

${ }^{2}$ Data incomplete because of rodent injury to the probe wires.

December and March, and summer plant quality was rated in July, August, and September. Plant height and spread were measured in spring and fall. The following aesthetic qualities were evaluated by visual rating using a scale of 0-9: appearance $(9=$ no appreciable defect, $7=$ some foliage discoloration due to summer sun scald or winter bronzing, $5=50 \%$ of plant alive, and $0=$ dead); winter color $(9=$ green, $5=$ reddish brown, and $0=$ brown/graybrown); and bronzing ( $9=$ no bronzing, $5=$ $50 \%$ of foliage bronzed, and $0=$ all foliage bronzed). Bronzing is a term used to describe bronze or orange-brown foliage discoloration often associated with winter stress (cold temperature, desiccation, high light, etc.). At each site, leaf canopy and soil temperatures were monitored around one of the structures by thermocouples attached to a strip chart recorder. The weather data documented the distinct microclimates that were created by the structures, permitting an accurate description of diurnal as well as seasonal temperature patterns.

Analyses of variance were conducted by the MIXED procedure of SAS (SAS Institute, Cary, N.C.). In cases where significant interactions existed, the sums of squares were partitioned among levels of one main factor within each level of the other. Mean separation was applied to the levels of one factor within each level of the other factors involved in the interaction. All mean separation was by F protected $t$ test $(P \leq 0.05)$

\section{Results}

In Kansas, winter stress is the greatest threat to plant survival. Winter 1995-96 was one of extremes. Midwinter low temperatures of $-25^{\circ} \mathrm{C}$ at Manhattan and $-23^{\circ} \mathrm{C}$ at Wichita were recorded at local official weather stations, along with sharp 24-h drops of $31-32^{\circ} \mathrm{C}$ in January and March. Thermocouple data showed up to a $15.7{ }^{\circ} \mathrm{C}$ difference in canopy temperatures between NNW and ESE exposures on the day when lowest temperatures were recorded (Table 1). Extremely dry, desiccating conditions persisted throughout the Winter 1995-96. In contrast, the following two winters were milder, with $-19^{\circ} \mathrm{C}$ being the lowest temperature recorded (Manhattan, 11 Jan. 1997). Variation in dieback and mortality following winter stress was noted between species at different sites and exposures. Plants of 'Winter Gem' suffered dieback at southern exposures SSE, S, WSW, and SSW in Manhattan, and at ESE in Wichita; one 'Winter Gem' plant died at southern exposure WSW and one 'Green Mountain' plant died at southern exposure SSW in Manhattan. Cold injury, reflected by degree of bronzing, was exposure-dependent for all cultivars irrespective of site (data not shown.). Bronzing was more severe at southern exposures SSE, ESE, S, WSW, and SSW for 'Green Velvet' and at SSE, S, and SSW for 'Green Mountain'. Both severity of winter and exposure affected degree of bronzing in 'Winter Gem'. Quality of overall winter appearance differed between cultivars, sites, and exposures (Table 2). The conditions of 'Green Mountain' and 'Green Velvet' at southern exposures S and WSW in Manhattan were significantly better than those of 'Winter Gem'. Similarly, 'Green Velvet' outperformed 'Winter Gem' at Manhattan exposure SSE. 'Winter Gem' appeared significantly better at Wichita southern exposures S, SSE, SSW, and WSW than at equivalent exposures in Manhattan.

Recovery from winter dieback and growth during Summer 1996 following the harsh Winter 1995-96 varied with cultivar, site, and exposure (Table 3). 'Winter Gem' grew most in height, with best growth exhibited at ESE and NNE exposures in Wichita. Growth of 'Green Mountain' and 'Green Velvet' was similar, with slightly greater increases occurring in Manhattan and 'Green Velvet' performing slightly better. Both 'Green Mountain' and 'Green Velvet' showed the greatest recovery growth at exposure WNW regardless of site. Total growth of the two cultivars over the period of the study did not differ significantly except at exposure $\mathrm{N}$ in Manhattan, where 'Green Velvet' grew more in height (Table 3). Total growth of the two cultivars also did not differ significantly between sites, although the greatest changes at both locations were found to be exposure-dependent. Growth of 'Winter Gem' over the period of the study was significantly greater than that of both
'Green Mountain' and 'Green Velvet', and was both site- and exposure-dependent, with significantly better growth at ENE, NNE, E, ESE, and WSW exposures in Wichita.

Kansas summer heat can place as much stress on ornamental plants as can winter cold and desiccating winds. Summer 1996 was typically hot and dry. Thermocouple data showed soil temperatures as high as $29^{\circ} \mathrm{C}$ at Wichita and $25.6^{\circ} \mathrm{C}$ at Manhattan on the days when highest temperatures were recorded (Table 4). Canopy temperatures varied as much as $17.8^{\circ} \mathrm{C}$ between NNW and SSE exposures at Manhattan. Heat stress was reflected in the degree of foliage sun scald and overall quality of summer appearance. Plant condition differed between cultivars, sites, and exposures (Table 2). 'Green Velvet' performed significantly better than 'Green Mountain' at southern exposures ESE, SSE, SSW, and WSW in Manhattan. 'Green Velvet' also outperformed 'Winter Gem' at Manhattan exposures S, SSE, and WSW and at Wichita exposure ESE. The condition of both 'Green Velvet' and 'Winter Gem' was significantly better than that of 'Green Mountain' at the WSW exposure in Wichita. 'Winter Gem' appeared significantly better at Wichita southern exposures S, SSW, and WSW than at equivalent exposures in Manhattan. Similarly, 'Green Mountain' looked better at Wichita exposure SSW than at its equivalent in Manhattan.

\section{Conclusion}

The best overall performance was exhibited by 'Green Velvet' and 'Green Mountain' with the former showing better performance at the Manhattan site. 'Green Velvet' had better winter foliage quality in Wichita, though the bronzing differences were less noticeable at the colder location (Zone 5), where both 'Green Velvet' and 'Green Mountain' displayed considerable bronzing. Both 'Green Velvet' and 'Green Mountain' performed adequately under all exposures, but their performance was consistently better in ENE, NNE, E, ESE, and WSW exposures. If more rapid growth rates are considered an advantage, then 'Green Velvet' should be selected over 'Green Mountain'. 'Winter Gem' suffered considerable 
winter dieback during Winter 1995-96, especially at the Manhattan site. However, subsequent relatively mild winters and a rapid growth rate enabled it to attain a size larger than either 'Green Velvet' or 'Green Mountain' at the end of the experiment. Though lacking in hardiness, 'Winter Gem' could still be used in protected sites.

\section{Literature Cited}

Batdorf, L.R. 1995. Boxwood handbook. Amer. Boxwood Soc., Boyce, Va.

Hawke, R. 1994. Plant evaluation notes: Boxwoods for northern midwest landscapes. Chicago Botanic Garden 6:1-4.

Martinez, H. 1995. Buxus microphylla var. koreana, hardy boxwood variety is a good choice for north- ern climates. Nursery Mgt. \& Prod. Oct., p. 11.

Pair, J.C. 1987. Winter hardiness, leaf-water potential, and heat tolerance of China Girl ${ }^{\circledR}$ holly as affected by landscape exposure. HortScience 22:268-270.

Pair, J.C. and S.M. Still. 1982. Growth, hardiness, and leaf-water potential of blue holly (Ilex xmeserveae) cultivars as affected by exposure. HortScience 17:823-825. 